\title{
PENGEMBANGAN MEDIA PEMBELAJARAN "MATBEL LEGENDA" BERBASIS KOMPUTER UNTUK MENUMBUHKAN RASA CINTA TANAH AIR
}

\author{
Sri Rizki Amalia ${ }^{1}$, Maharani Izzatin ${ }^{2}$, Alfian Mucti $^{3}$ \\ ${ }^{1}$ Mahasiswa Strata 1 Pendidikan Matematika, Universitas Borneo Tarakan \\ ${ }^{2,3}$ Jurusan Pendidikan Matematika, Universitas Borneo Tarakan \\ 1 srizkiamalia.ra@gmail.com \\ ${ }^{2}$ maharaniizzatinubt@gmail.com \\ 3alfianmucti@borneo.ac.id
}

\begin{abstract}
The purpose of this research was to produce the application of "Matbel Legenda" with computer based which was worthy as mathematics learning to grow the feeling of loving the homeland of VIII graders in SMP Negeri 7 Tarakan on Teorema Pythagoras materials. The type of this research was Research and Development (R \& D) which was conducted at SMP Negeri 7 Tarakan in class VIII. The development model used was ADDIE model. Overall, ADDIE model consists of 5 stages. The stages are started from Analysis, Design, Development, Implementation, and Evaluation. The development stage was conducted by making the learning media "Matbel Legenda", validated by the content expert, learning design expert, language and culture expert, media expert, and the testing was conducted in 2 stages with small group test which consisted of 6 students as the subjects and field test which consisted of 28 students as the subjects. The analysis showed that the learning media "Matbel Legenda" which was developed based on the validation of content expert got average score of 3,5 with very good category, the learning design expert got average score of 3,4 with very good category, the language and culture expert got average score of 3,8 with very good category, and the media expert got average score of 3,4 with very good category. Furthermore, the result from field test for "Matbel Legenda" had fulfilled the requirements as a product that was easy to operate, easy to learn, and has attractive appearance. The "Matbel Legenda" learning media based on computer to grow the students' feeling of loving the homeland has an analysis result as Normalized gain of 0,6 with medium category. Because of that, the "Matbel Legenda" learning media was worthy to be used as additional learning media to grow the feeling of loving the homeland of VIII graders in SMP Negeri 7 Tarakan.
\end{abstract}

Keywords: Matbel Legenda, ADDIE Development Model, The Feeling of Loving the Homeland.

\begin{abstract}
Abstrak
Penelitian ini bertujuan untuk menghasilkan produk media pembelajaran "Matbel Legenda" yang layak sebagai media pembelajaran untuk siswa kelas VIII SMP Negeri 7 Tarakan pada materi Teorema Pythagoras. Penelitian ini dilaksanakan pada semester genap tahun ajaran 2018/2019 di SMP Negeri 7 Tarakan. Jenis penelitian ini adalah penelitian dan pengembangan (Research and Development) dengan model penelitian dan pengembangan yang digunakan adalah model ADDIE yang terdiri dari Analyze (analisis), Design (desain), Development (pengembangan), Implementation (implementasi), dan Evaluating (evaluasi). Tahap pengembangan dilakukan pembuatan media pembelajaran "Matbel Legenda" dan validasi oleh ahli isi atau materi, bahasa dan budaya, desain pembelajaran, dan media. Selanjutnya, media pembelajaran "Matbel Legenda" dilakukan sebanyak 2 tahapan yaitu 1) uji coba terbatas dilakukan terhadap 6 orang siswa, 2) uji coba lapangan dilakukan terhadap 28 orang siswa. Hasil analisis menunjukkan bahwa media pembelajaran "Matbel Legenda" yang dikembangkan berdasarkan validasi ahli materi memperoleh skor 29 dengan kategori sangat baik serta memperoleh persentase kelayakan sebesar 90,63\% berada pada kategori sangat layak, ahli desain pembelajaran memperoleh skor 59 dengan kategori sangat baik serta memperoleh persentase kelayakan sebesar $86,76 \%$ berada pada kategori sangat layak, ahli bahasa dan budaya memperoleh skor 19 dengan kategori sangat baik serta memperoleh persentase kelayakan sebesar 95\% berada pada kategori sangat layak, dan ahli media memperoleh skor 79 dengan kategori sangat baik serta memperoleh persentase kelayakan sebesar $85,87 \%$ berada pada kategori sangat layak. Selanjutnya, hasil uji coba di lapangan menunjukkan bahwa media pembelajaran "Matbel Legenda" telah memenuhi syarat kemudahan produk dioperasikan, kemudahan produk dipelajari, serta tampilan dan desain. Media pembelajaran "Matbel Legenda" berbasis komputer untuk menumbuhkan rasa cinta tanah air siswa memiliki hasil analisis Normalized gain yaitu 0,6 dengan kategori sedang. Dengan demikian, media
\end{abstract}


pembelajaran "Matbel Legenda" dapat dikatakan layak untuk digunakan sebagai media pembelajaran untuk menumbuhkan rasa cinta tanah air siswa kelas VIII SMP Negeri 7 Tarakan.

Kata kunci: Matbel Legenda, Model Pengembangan ADDIE, Rasa Cinta Tanah Air.

Pasal 1 ayat (2) Undang-Undang Nomor 20 Tahun 2003, pendidikan nasional haruslah didasarkan oleh Pancasila dan Undang-Undang Dasar Negara Republik Indonesia Tahun 1945 yang berakar pada nilai-nilai agama, kebudayaan nasional Indonesia dan tanggap terhadap tuntutan perubahan zaman. Oleh karena itu, pelaksanaan pendidikan harus sesuai dengan karakter budaya bangsa Indonesia. Nilai-nilai budaya tersebut dapat ditanamkan melalui pendidikan. Pendidikan dan budaya dapat dijadikan sebagai alat untuk menumbuhkan dan mengembangkan karakter bangsa, salah satunya yaitu karakter cinta tanah air. Hal ini sejalan dengan pendapat Ulya (2016: 33), pendidikan dengan berbasis nilai-nilai kebudayaan tradisional dapat dijadikan alternatif dalam menumbuhkan karakter rasa cinta tanah air.

Matematika sebagai bagian dari pendidikan memiliki tanggungjawab yang sama dengan mata pelajaran lain untuk mengembangakan karakter siswa sebagai calon generasi masa depan, terutama karakter rasa cinta tanah air. Proses pembelajaran matematika di sekolah seharusnya dapat membantu untuk menumbukan karakter rasa cinta tanah air. Faktanya, proses pembelajaran matematika masih belum dihubungkan dengan karakter rasa cinta tanah air seperti kebudayaan daerah.

Berdasarkan observasi yang dilakukan di SMP Negeri 7 Tarakan, diperoleh informasi bahwa masih banyak siswa yang tidak memperhatikan saat guru menjelaskan pelajaran. Selain itu juga, beberapa siswa yang duduk di belakang sibuk dengan kegiatannya sendiri sehingga mengganggu proses pembelajaran. Selain itu, didukung juga dengan wawancara guru matematika kelas VIII pada tanggal 27 Februari 2018, diperoleh informasi bahwa minat belajar siswa terhadap pembelajaran matematika sangat rendah, dikarenakan menurut para siswa, pelajaran matematika itu sulit dipahami. Guru juga menambahkan, kebanyakan siswa kelas VIII masih kesulitan terutama pada materi Teorema Pythagoras.

Pernyataan guru tersebut juga didukung dengan angket yang disebarkan peneliti di SMP Negeri 7 Tarakan, dimana sebesar 57\% siswa kurang bersemangat dalam pembelajaran matematika, sebanyak 55\% siswa menganggap bahwa guru mengajarkan matematika dengan cara yang tidak menarik. Selain itu, hanya sekitar $41 \%$ siswa yang menganggap pembelajaran matematika yang didapatkan dari sekolah cukup baik. Salah satu penyebabnya dikarenakan pembelajaran matematika yang kurang menarik, dimana masih kurangnya penggunaan media dalam pembelajaran. Hal ini juga dikemukakan oleh guru matematika SMP Negeri 7 Tarakan, bahwa pembelajaran matematika belum memanfaatkan fasilitas sekolah sebagai media pembelajarannya, seperti komputer pada saat pembelajaran.

Menurut Puspadewi (2016), matematika merupakan bagian dari kebudayaan, diterapkan dan digunakan untuk menganalisis yang sifatnya inovatif. Faktanya, proses pembelajaran matematika 
masih belum dihubungkan dengan karakter cinta tanah air seperti kebudayaan daerah. Hal ini juga diungkapkan guru matematika di SMP Negeri 7 Tarakan yang menyebutkan bahwa belum pernah menghubungkan pembelajaran matematika dengan kebudayaan daerah Kalimantan Utara.

Salah satu cara untuk menjembatani antara budaya dan pembelajaran matematika adalah dengan menerapkan pembelajaran matematika berbasis kebudayaan. Melalui penerapan pembelajaran matematika berbasis kebudayaan diharapkan siswa dapat lebih memahami matematika dan budaya, sehingga para guru akan lebih mudah untuk menanamkan nilai budaya dalam diri siswa. Nilai budaya tersebut diharapkan akan dapat menumbuhkan rasa cinta tanah air siswa.Berdasarkan uraian diatas, maka peneliti bermaksud untuk melakukan penelitian tentang pengembangan "Matbel Legenda" yang merupakan Matematika Belajar Legenda (Cerita Rakyat) dari Kalimantan Utara Berbasis Komputer sebagai Media Pembelajaran Matematika untuk Menumbuhkan Rasa Cinta Tanah Air Siswa Kelas VIII SMP Negeri 7 Tarakan. Tujuan yang ingin dicapai pada penelitian ini adalah mengembangkan produk berupa "Matbel Legenda" berbasis komputer yang layak sebagai media pembelajaran matematika untuk menumbuhkan rasa cinta tanah air bagi siswa kelas VIII SMP Negeri 7 Tarakan.

Menurut Susilana (2011: 7), media pembelajaran adalah sarana komunikasi dalam bentuk cetak maupun non cetak, termasuk teknologi perangkat kerasnya dan media pembelajaran selalu terdiri atas dua unsur penting, yaitu unsur peralatan atau perangkat keras (hardware) dan unsur pesan yang dibawahnya (message/ software). Leshin (dalam Arsyad, 2015: 82-90), berpendapat bahwa media pembelajaran yang dapat digunakan sebagai sarana belajar siswa terdiri dari beberapa macam, yaitu media berbasis manusia, media berbasis cetakan, media berbasis visual, media berbasis audiovisual, dan media berbasis komputer. Pada penelitian dan pengembangan ini termasuk media berbasis komputer.

Pembelajaran berbasis komputer merupakan program pembelajaran yang digunakan dalam proses pembelajaran dengan menggunakan software komputer berupa program komputer yang berisi tentang muatan pembelajaran meliputi: judul, tujuan, materi pembelajaran, dan evaluasi pembelajaran (Rusman, 2012: 153).Rusman (2012: 154) menambahkan bawa terdapat empat jenis pembelajaran berbasis komputer yaitu latihan, penjelasan, simulasi dan permainan. Pada penelitian dan pengembangan ini termasuk pada gabungan antara penjelasan dan permainan.Menurut Chee dan Wong (dalam Sugiarti, 2017: 1064) berpendapat bahwa kelayakan media berbasis komputer ditinjau dari Appropriatennes, Accuracy, Currency, dan Clarity (Keakuratan, Kemutakhiran, dan Kejelasan), serta Scene Presentation dan Design (Tampilan dan Desain).

Kemendiknas (2010) mengemukakan bahwa cinta tanah air merupakan cara berpikir, bersikap dan berbuat yang menunjukkan kesetiaan, kepedulian, dan penghargaan yang tinggi terhadap bangsa, lingkungan fisik, sosial, budaya, ekonomi, dan politik bangsanya. Ditambahkan oleh Kusuma (2017), rasa cinta tanah air harus ditanamkan sejak dini oleh masyarakat Indonesia dengan tetap melestarikan budaya Indonesia yang sudah ada, khususnya pada generasi muda dapat memiliki rasa bangga terhadap bangsa Indonesia. Oleh karena itu, pendidikan berbasis nilai-nilai budaya daerah dapat 
dijadikan sebagai alternatif pendidikan karakter cinta tanah air.Menurut Yuliyanto (2014), indikator rasa cinta tanah air berbasis kebudayaan tradisional yaitu ketertarikan, kesetiaan, kepedulian, dan penghargaan terhadap budaya tradisional daerah.

Provinsi Kalimantan Utara merupakan provinsi termuda di Indonesia saat ini yang berada di bagian utara Pulau Kalimantan. Pembentukan Provinsi Kalimantan Utara berdasarkan UndangUndang No. 20 Tahun 2012 tentang Pembentukan Provinsi Kalimantan Utara. Provinsi Kalimantan Utara terdiri atas lima wilayah administrasi dengan empat kabupaten, yaitu Kabupaten Bulungan, Kabupaten Malinau, Kabupaten Nunukan, Kabupaten Tana Tidung, dan Kota Tarakan. Ibukota Provinsi Kalimantan Utara terletak di Tanjung Selor, yang saat ini berada di Kabupaten Bulungan.

Menurut Setyami, dkk (2014: 9), cerita rakyat adalah cerita yang berasal dari masyarakat dan berkembang dalam masyarakat pada masa lampau yang menjadi ciri khas setiap bangsa yang memiliki kultur budaya yang beraneka ragam mencakup kekayaan budaya dan sejarah yang dimiliki masing-masing bangsa. Setyami, dkk (2018: 14-68) menambahkan, bahwa cerita rakyat yang terdapat di Provinsi Kalimantan Utara yaitu Yaki Yamus, Betawol, Benayuk (versi 1), Benayuk (versi 2), Aki Balak, Asal Mula Gunung Srilaki, Perahu Bersisik, Asal-usul Tidung Berbatu, Keris Tulang Bawang, Yadu Usuk, Si Gumban, serta Putri Kumalasari dan Buluh Perindu.

Construct 2 merupakan sebuah game engine 2D untuk HTML 5 yang dikembangkan oleh Scirra Ltd. Game engine ini dikembangkan dengan konsep behavior \& event attachment, sehingga logika dalam game dapat dibangun tanpa harus mengetikkan suatu coding. Software inilah yang digunakan untuk mengembangkan media pembelajaran "Matbel Legenda"

\section{METODE}

Jenis penelitian yang digunakan adalah penelitian dan pengembangan (research and development) dengan menggunakan model penelitian dan pengembangan ADDIE yang terdiri atas Analyze, Design, Development, Implentation, dan Evaluation. Penelitian pada semester genap tahun ajaran 2018/2019. Tempat pelaksanaan penelitian ini adalah SMP Negeri 7 Tarakan yang beralamat di Jalan Diponegoro Kelurahan Pamusian, Kecamatan Tarakan Tengah, Kota Tarakan.

Teknik pengumpulan data yang digunakan dalam penelitian ini adalah evaluasi dari beberapa ahli (ahli materi, ahli desain pembelajaran, ahli bahasa dan budaya, ahli media), subjek penelitian yakni siswa kelas VIII SMP Negeri 7 Tarakan yakni 6 siswa sebagai subjek uji coba kelompok kecil dan 28 siswa sebagai subjek uji coba lapangan, dan angket rasa cinta tanah air.

Dalam penelitian ini penelitian menggunakan dua macam analisis data, yaitu deskriptif dan statistik deskriptif. Analisis deskriptif digunakan untuk mengetahui komentar dan saran yang dikemukakan oleh para ahli materi, ahli desain pembelajaran, ahli bahasa dan budaya, ahli media dan siswa sebagai subjek penelitian. Sedangkan, analisis statistik deskriptif digunakan untuk menganalisis data yang diperoleh dari angket hasil validasi para ahli materi, ahli desain pembelajaran, ahli bahasa dan budaya, ahli media dan data yang diperoleh dari angket tanggapan 
siswa terhadap produk yang dikembangkan dan juga tanggapan siswa terhadap rasa cinta tanah air dalam hal ini menggunakan cerita rakyat Kalimantan Utara dalam media pembelajaran yang dikembangkan.

Untuk menganalisis data tentang kelayakan media pembelajaran berdasarkan angket yang disebar, angket tersebut dibuat dengan skala Likert. Adapun pedoman penskoran tiap lembar validasi ahli dan tanggapan siswa menggunakan skala Likert oleh Sugiyono (2016: 166) seperti pada tabel berikut ini.

\begin{tabular}{cc} 
Tabel1. Pedoman Penskoran dengan Skala Likert \\
\hline Kategori & Skor \\
Sangat Baik (SB) & 4 \\
Baik (B) & 3 \\
Kurang (K) & 2 \\
Sangat Kurang (SK) & 1 \\
\hline (Sumber : Konversi dari Sugiyono, 2016)
\end{tabular}

Data kelayakan melewati beberapa tahapan analisis dengan langkah-langkah sebagai berikut:

1) Menghitung jumlah skor penelitian tiap indikator

2) Kategorikan skor tersebut ke dalam kriteria penilaian yang disajikan dalam tabel kriteria penilaian menggunakan acuan konversi dari Mardapi (2008: 123)

Tabel 2. Kriteria Penilaian Data Validasi Ahli dan Tanggapan Siswa

\begin{tabular}{cc}
\hline Interval Skor & Kategori \\
\hline$X \geq M i+1 . S b i$ & Sangat Baik \\
\hline$M i+1 . S b i>X \geq M i$ & Baik \\
\hline$M i>X \geq M i-1 . S b i$ & Kurang \\
\hline$X<M i-1 . S b i$ & Sangat Kurang \\
\hline (Sumber : Konversi dari Mardapi, 2008)
\end{tabular}

Dari skala 4 di atas diketahui bahwa skor maksimal ideal $=4$ dan skor minimal ideal $=1$, sehingga diperoleh perhitungan $\overline{\mathrm{X}}$ dan SBx sebagai berikut:

$$
\begin{gathered}
\bar{X}=\frac{1}{2}(4+1)=2,5 \\
\mathrm{SBX}=\frac{1}{6}(4-1)=0,5
\end{gathered}
$$

Hasil dari perhitungan di atas maka didapatkan pedoman konversi skor validasi ahli dan tanggapan siswa seperti berikut ini:

Tabel 3. Pedoman Konversi Skor Validasi Ahli dan Tanggapan Siswa

\begin{tabular}{cc}
\hline Interval Skor & Kategori \\
\hline $\mathrm{X} \geq 3$ & Sangat Baik \\
\hline $3>\mathrm{X} \geq 2,5$ & Baik \\
\hline $2,5>\mathrm{X} \geq 2$ & Kurang \\
\hline $\mathrm{X}<2$ & Sangat Kurang \\
\hline
\end{tabular}

(Sumber : Konversi dari Mardapi, 2008)

3) Menghitung persentase kelayakan tiap aspek (\%) menggunakan perhitungan berikut ini.

Persentase Kelayakan $(\%)=\frac{\sum \text { Jumlah skor tiap indikator }}{\sum \text { Jumlah skor ideal }} \times 100 \%$

4) Data yang sudah terhitung dengan persentase kelayakan, selanjutnya akan dianalisis sesuai dengan pendapat Arikunto (2010: 158) pada tabel berikut ini. 
Tabel 4. Skala Persentase Uji Kelayakan

\begin{tabular}{cc}
\hline Interval Skor & Kategori \\
\hline $76 \%-100 \%$ & Sangat Layak \\
\hline $51 \%-75 \%$ & Layak \\
\hline $26 \%-50 \%$ & Kurang Layak \\
\hline $0 \%-25 \%$ & Tidak Layak \\
\hline (Sumber : Konversi dari Arikunto, 1996)
\end{tabular}

Kriteria kelayakan produk yang dikembangkan dapat dikatakan sudah dapat digunakan apabila hasil penilaian dari ahli materi, ahli desain pembelajaran, ahli bahasa dan budaya, ahli media, dan uji coba siswa memperoleh kategori minimal layak.

Data angket rasa cinta tanah air siswa diperoleh dari hasil angket rasa cinta tanah air oleh siswa sebelum dan sesudah penggunaan media pembelajaran "Matbel Legenda". Untuk menganalisis data rasa cinta tanah air, maka digunakan perhitungan data skor rata-rata gain yang dinormalisasi (Normalized Gain) yang dikembangkan oleh Hake (1998) dengan menggunakan rumus sebagai berikut.

$$
\langle\mathrm{g}\rangle=\frac{\text { Posttest Score-Pretest Score }}{\text { Maximum Possible Score-Pretest Score }}
$$

Rata-rata Normalized Gain <g> merupakan selisih nilai tes awal dan tes akhir dari rata-rata kelas. Maximum Possible Score adalah skor maksimal dari tes. Pretest score adalah skor tes awal, sedangkan Posttest score adalah skor tes akhir.

Nilai rata-rata gain yang telah diperoleh, kemudian dikategorikan berdasarkan pada tabel.

Tabel 5. Kategori Skor Normalized Gain pada Angket Rasa Cinta Tanah Air

\begin{tabular}{cc}
\hline Interval Skor & Kategori \\
\hline$\langle\mathrm{g}\rangle \geq 0,7$ & Tinggi \\
\hline $0,3 \leq<\mathrm{g}><0,7$ & Sedang \\
\hline$<\mathrm{g}><0,3$ & Rendah \\
\hline
\end{tabular}

(Sumber: Hake, 1998)

\section{HASIL DAN PEMBAHASAN}

Pada tahap Analysis (Analisis) yaitu melakukan analisis kebutuhan, analisis kurikulum, analisis teknologi, dan analisis kebudayaan Kalimantan Utara. Sedangkan pada tahap Design (Desain) yaitu membuat desain awal media pembelajaran "Matbel Legenda". Setelah itu, pada tahap Development (Pengembangan), media pembelajaran mulai dibuat kemudian divalidasi oleh para ahli (ahli materi, ahli desain pembelajaran, ahli bahasa dan budaya, serta ahli media). Berikut hasil yang diperoleh dari validasi para ahli:

\section{a. Ahli Materi}

Validasi ahli materi memperoleh skor 29 dengan rata-rata skor 3,6 pada kategori sangat baik. Persentase kelayakan sebesar 90,63\% dengan kategori sangat layak. Pada indikator kesesuaian media dengan karakteristik siswa, memberi kesempatan siswa untuk belajar mandiri, dan memperhatikan perbedaan individu berada pada kategori baik. Diperolehnya kategori baik karena komponen indikator yang dibuat sudah sesuai dengan apa yang dibutuhkan dalam media pembelajaran "Matbel Legenda". Sebagai contoh, indikator memberi kesempatan siswa untuk belajar mandiri, ahli isi atau materi beranggapan bahwa media pembelajaran "Matbel Legenda" ini dapat membantu siswa dalam belajar 
mandiri baik di rumah maupun di sekolah. Selanjutnya, indikator Kesesuaian KI/KD matematika Kurikulum 2013, Kesesuaian Indikator Pencapaian Kompetensi dengan KI/KD, kesesuaian materi dengan ruang lingkup matematika, kesesuaian cara penyampaian materi dengan perkembangan siswa, dan indikator menuntut aktifitas berada pada kategori sangat baik. Selain itu juga, ahli isi atau materi menambahkan saran khususnya pada game, dimana perlunya menambahkan respon pilihan jawaban saat kursor melewati pilihan jawaban, misalnya jika diklik ada respon/perubahan warna.

b. Ahli Desain Pembelajaran

Validasi ahli desain pembelajaran memperoleh skor 59 dengan rata-rata skor 3,5 pada kategori sangat baik. Persentase kelayakan sebesar 86,76\% dengan kategori sangat layak. Pada indikator kejelasan judul program, kemenarikan judul program, kesesuaian apersepsi dengan tujuan dan materi pembelajaran, ketepatan urutan penyajian materi, keakuratan materi, pemberian contoh mendukung pemahaman siswa terhadap materi, daya tarik game sebagai media pembelajaran, dan indikator kesesuaian soal yang digunakan dengan indikator pencapaian kompetensi, berada pada kategori sangat baik. Selanjutnya, pada indikator kejelasan isi materi, kelengkapan rangkuman materi yang disajikan, kemenarikan variasi penyampaian materi, kesesuaian isi materi dengan cerita rakyat Kalimantan Utara, kemutakhiran evaluasi belajar berupa game, kualitas butir soal yang digunakan, tingkat kesulitan soal yang digunakan, kunci jawaban sesuai dengan soal yang diberikan, dan indikator kualitas umpan balik berada pada kategori baik. Diperolehnya kategori baik karena komponen indikator yang dibuat sudah sesuai dengan apa yang dibutuhkan dalam media pembelajaran "Matbel Legenda". Sebagai contoh indikator kesesuaian isi materi dengan cerita rakyat Kalimantan Utara, ahli desain pembelajaran beranggapan bahwa materi Teorema Pythagoras yang digunakan dalam media pembelajaran "Matbel Legenda" sudah sesuai dengan cerita rakyat yang terdapat di daerah Kalimantan Utara. Selain itu, ahli desain pembelajaran juga menambahkan saran yaitu penambahan suara pada materi, memperbaiki definisi Triple Pythagoras, dan mengubah beberapa soal yang masih kurang sesuai.

\section{c. Ahli Bahasa dan Budaya}

Validasi ahli bahasa dan budaya memperoleh skor 19 dengan rata-rata skor 3,8 pada kategori sangat baik. Persentase kelayakan sebesar 95\% dengan kategori sangat layak. Pada indikator kebenaran cerita rakyat Kalimantan Utara yang digunakan, kebenaran baju adat Kalimantan Utara yang ditampilkan pada media, kebenaran lagu atau instrumen dari Kalimantan Utara, dan indikator kesesuaian bahasa dengan sasaran pengguna berada pada kategori sangat baik. Sedangkan pada indikator kejelasan penggunaan bahasa berada pada kategori baik. Diperolehnya kategori baik karena komponen indikator yang dibuat sudah sesuai dengan apa yang dibutuhkan dalam media pembelajaran "Matbel Legenda". Saran yang diberikan oleh ahli bahasa dan budaya yakni pada aspek bahasa, dimana sebaiknya penggunaan kata "Legends" dalam media pembelajaran diubah menjadi "Legenda", selain itu disarankan untuk menambahkan sumber pada halaman "Cerita Rakyat Kalimantan Utara". 
Pengembangan Media Pembelajaran "Matbel Legenda” Berbasis Komputer Untuk Menumbuhkan Rasa Cinta Tanah Air, Sri Rizki Amalia, Maharani Izzatin, Alfian Mucti

\section{d. Ahli Media}

Validasi ahli materi memperoleh skor 79 dengan rata-rata skor 3,4 pada kategori sangat baik. Persentase kelayakan sebesar $85,87 \%$ dengan kategori sangat layak. Berdasarkan tabel 4.13, diperoleh bahwa pada indikator ketepatan pemilihan jenis huruf, ukuran gambar, kualitas tampilan gambar, kemenarikan sampul depan, kesesuaian tampilan dengan isi, kesesuaian dengan pengguna, fleksibilitas (dapat digunakan dengan mandiri dan terbimbing), tampilan petunjuk penggunaan, kemudahan berinteraksi dengan pemrograman, dan indikator ketepatan penggunaan tombol navigasi, berada pada kategori sangat baik. Sedangkan pada indikator kesesuaian penggunaan background, kesesuaian proporsi layout, ketepatan pemilihan ukuran huruf, keterbacaan teks yang digunakan, kesesuaian warna tulisan dengan warna background, komposisi gambar, kesesuaian animasi dengan materi, kemenarikan penggunaan animasi, ketepatan pemilihan backsound dengan materi, kejelasan musik atau suara, kualitas video cerita rakyat, kejelasan petunjuk penggunaan,dan indikator konsistensi penempatan tombol navigasi, berada pada kategori baik. Diperolehnya kategori baik karena komponen indikator yang dibuat sudah sesuai dengan apa yang dibutuhkan dalam media pembelajaran "Matbel Legenda". Sebagai contoh pada indikator konsistensi penempatan tombol berada pada kategori baik karena menurut ahli media, pada media pembelajaran "Matbel Legenda" masih ada beberapa halaman yang masih belum konsisten penempatan tombolnya. Saran yang diberikan adalah memperbaiki konsistensi tombol dan memperbaiki petunjuk penggunaan media pembelajaran.

\section{e. Uji coba kelompok kecil}

Uji coba kecil dilakukan sebanyak 6 orang siswa. Diperoleh data pada aspek kemudahan produk untuk dioperasikan memperoleh skor 35,8 dengan rata-rata skor 3,6 pada kategori sangat baik. Persentase kelayakan sebesar $89,5 \%$ dengan kategori sangat layak. Pada indikator kemudahan memulai program, kemudahan mengakhiri program, kemudahan memilih menu program, kejelasan petunjuk penggunaan program, kemudahan menggunakan tombol, tingkat kemudahan menggunakan program, kejelasan petunjuk mengerjakan soal pada program, kebebasan memilih menu program, kemudahan menjalankan program, kehandalan media selama dijalankan, kefektifan game sebagai media pembelajaran, dan daya tarik game sebagai media pembelajaran berada pada kategori sangat baik. Hal ini dikarenakan menurut siswa komponen indikator tersebut sudah sangat sesuai dengan apa yang siswa harapkan. Sebagai contoh indikator keefektifan game sebagai media pembelajaran, siswa beranggapan bahwa dengan adanya evaluasi pembelajaran terutama dalam bentuk permainan, dapat memacu semangat siswa dalam pembelajaran.

Pada aspek kemudahan produk untuk dipelajari memperoleh skor 35,2 dengan rata-rata skor 3,9 pada kategori sangat baik. Persentase kelayakan sebesar 97,78\% dengan kategori sangat layak. Pada indikator kejelasan uraian materi, penyampaian materi menarik, ketepatan urutan penyajian materi, teks dapat dibaca dengan jelas, penggunaan gaya bahasa yang mendukung pemahaman siswa terhadap materi dan latihan soal, pemberian contoh soal mendukung pemahaman siswa terhadap 
materi, kejelasan butir soal, kejelasan perintah soal untuk diselesaikan, dan keterkaitan materi dengan cerita rakyat Kalimantan Utara berada pada kategori sangat baik. Hal ini dikarenakan siswa beranggapan bahwa komponen indikator tersebut sudah sesuai dengan media "Matbel Legenda" yang dikembangkan baik untuk dijadikan sebagai media pembelajaran di dalam kelas. Selain itu juga, dengan menggabungkan materi matematika khususnya Teorema Pythagoras dengan cerita rakyat dari Kalimantan Utara dapat menambah ketertarikan siswa dalam pembelajaran.

Pada aspek keindahan tampilan memperoleh skor 27 dengan rata-rata skor 3,8 pada kategori sangat baik. Persentase kelayakan sebesar 96,43\% dengan kategori sangat layak. Pada indikator keindahan warna latar, keindahan desain, kesesuaian latar dengan warna huruf yang digunakan, keserasian pilihan jenis huruf, ukuran huruf, dan warna huruf, keserasian dan keindahan tombol, ketepatan penggunaan audio atau musik, dan kemenarikan cerita rakyat yang ditampilkan berada pada kategori sangat baik. Hal ini dikarenakan siswa beranggapan bahwa tampilan yang disajikan sudah sangat menarik dan dapat membuat siswa tertarik untuk menggunakan "Matbel Legenda" sebagai media pembelajaran matematika.

f. Uji Coba Lapangan

Uji coba lapangan dilakukan oleh 28 siswa. Pada aspek kemudahan produk dioperasikan memperoleh skor 36,3 dengan rata-rata skor 3,6 pada kategori sangat baik. Persentase kelayakan sebesar 90,75\% dengan kategori sangat layak. Pada indikator kemudahan memulai program, kemudahan mengakhiri program, kemudahan memilih menu program, kejelasan petunjuk penggunaan program, kemudahan menggunakan tombol, tingkat kemudahan menggunakan program, kejelasan petunjuk mengerjakan soal pada program, kebebasan memilih menu program, kemudahan menjalankan program, kehandalan media selama dijalankan, kefektifan game sebagai media pembelajaran, dan daya tarik game sebagai media pembelajaran berada pada kategori sangat baik. Hal ini dikarenakan menurut siswa media pembelajaran "Matbel Legenda" mudah dioperasikan baik dari segi materi dan juga permainannya, selain itu media pembelajaran ini sangat efektif digunakan dalam pembelajaran di kelas secara mandiri ataupun berkelompok.

Sedangkan, pada aspek kemudahan produk untuk dipelajari memperoleh skor 31,6 dengan rata-rata skor 3,5 pada kategori sangat baik. Persentase kelayakan sebesar 87,78\% dengan kategori sangat layak. Pada indikator kejelasan uraian materi, penyampaian materi menarik, ketepatan urutan penyajian materi, teks dapat dibaca dengan jelas, penggunaan gaya bahasa yang mendukung pemahaman siswa terhadap materi dan latihan soal, pemberian contoh soal mendukung pemahaman siswa terhadap materi, kejelasan butir soal, kejelasan perintah soal untuk diselesaikan, dan keterkaitan materi dengan cerita rakyat Kalimantan Utara berada pada kategori sangat baik. Hal ini dikarenkan menurut siswa, media pembelajaran "Matbel Legenda" ini sangat mudah dipelajari, materi yang terdapat dalam media ini jelas dan lengkap, serta terdapat contoh soal yang mudah dipahami dan juga latihan soal yang menarik karena disertai dengan permainan. 
Aspek keindahan tampilan memperoleh skor 24,4 dengan rata-rata skor 3,5 pada kategori sangat baik. Persentase kelayakan sebesar $87,14 \%$ dengan kategori sangat layak. Pada indikator keindahan warna latar, keindahan desain, kesesuaian latar dengan warna huruf yang digunakan, keserasian pilihan jenis huruf, ukuran huruf, dan warna huruf, keserasian dan keindahan tombol, dan ketepatan penggunaan audio atau musik berada pada kategori sangat baik. Hal ini dikarenakan siswa beranggapan bahwa tampilan pada media pembelajaran "Matbel Legenda". Sebagai contoh dari segi keindahan desain serta ketepatan penggunaan musik dari daerah Kalimantan Utara membuat siswa menjadi lebih menarik dan mengetahui kebudayan tradisional Kalimantan Utara yang lainnya. Begitu pula dengan ukuran huruf ataupun jenis huruf yang digunakan dapat dibaca dengan jelas ketika sedang menjalankan game tersebut.

Pada tahap ini, siswa juga diberikan angket rasa cinta tanah air sebelum dan sesudah menggunakan media. Hal ini untuk mengetahui efektivitas pengembangan media dalam menumbuhkan rasa cinta tanah air siswa. Pertumbuhan rasa cinta tanah air siswa dapat dilihat dari pengukuran rasa cinta tanah air sebelum dan sesudah penggunaan media pembelajaran. Angket berisi 27 butir pertanyaan yang terdiri dari 14 butir pernyataan positif dan 13 butir pernyataan negatif. Dimana, rasa cinta tanah air siswa sebelum penggunaan media sebesar 69,50 skor rata-rata kelas dan setelah penggunaan media pembelajaran "Matbel Legenda", rasa cinta tanah air siswa memperoleh skor rata-rata kelas yaitu sebesar 92,44 . Selanjutnya, data tersebut diolah dengan menggunakan rumus Normalized Gain sehingga diperoleh data pertumbuhan rasa cinta tanah air siswa menggunakan media "Matbel Legenda" sebesar 0,6 dengan kategori sedang.

Peningkatan rasa cinta tanah air terjadi dikarenakan sebelum penggunaan media pembelajaran "Matbel Legenda", siswa belum banyak mengetahui kebudayaan tradisional yang terdapat di Kalimantan Utara terutama cerita rakyatnya. Akan tetapi, setelah penggunaan media pembelajaran "Matbel Legenda", siswa sedikit banyak menjadi tahu kebudayaan Kalimantan Utara, khususnya cerita rakyat.

\section{KESIMPULAN}

Berdasarkan hasil analisis dan pembahasan, maka dapat disimpulkan bahwa:

1. Pengembangan media pembelajaran "Matbel Legenda" menggunakan model pengembangan ADDIE yaitu Analysis (Analisis), Design (Desain), Development (Pengembangan), Implementation (Implementasi), dan Evaluation (Evaluasi). Pada tahap pengembangan (Development) meliputi validasi dan uji coba produk. Produk divalidasi oleh ahli isi atau materi yang memperoleh kategori sangat layak, ahli desain pembelajaran memperoleh kategori sangat layak, ahli bahasa/budaya memperoleh kategori sangat layak, dan ahli media memperoleh kategori sangat layak. Setelah validasi produk ke para ahli dan mendapat kategori sangat layak serta dapat digunakan, media "Matbel Legenda" kemudian dilakukan uji coba produk kepada siswa. Uji coba produk kepada siswa, meliputi uji coba kelompok kecil, yang terdiri dari aspek 
kemudahan produk dioperasikan memperoleh kategori sangat layak, pada aspek kemudahan produk dipelajari memperoleh kategori sangat layak, dan pada aspek keindahan tampilan memperoleh kategori sangat layak. Selanjutnya, dilakukan uji coba lapangan, memperoleh kategori sangat layak, pada aspek kemudahan produk dipelajari memperoleh kategori sangat layak, dan pada aspek keindahan tampilan memperoleh kategori sangat layak. Hal ini menunjukkan bahwa media pembelajaran "Matbel Legenda" yang dikembangkan sangat layak untuk digunakan dalam proses pembelajaran.

2. Berdasarkan hasil analisis dengan Normalized Gain diperoleh nilai gain sebesar 0,6, dimana telah terjadi peningkatan rasa cinta tanah air siswa sebelum dan sesudah penggunaan media pembelajaran dan berada pada kategori sedang.

Karena telah memenuhi aspek kelayakan, keakuratan, kemutakhiran dan kejelasan, tampilan dan desain dan juga dapat menumbuhkan rasa cinta tanah air siswa, maka dapat disimpulkan bahwa media pembelajaran "Matbel Legenda" layak digunakan oleh siswa kelas VIII SMP Negeri 7 Tarakan dalam mempelajari materi Teorema Pythagoras, sekaligus dapat menumbuhkan rasa cinta tanah air siswa

\section{DAFTAR PUSTAKA}

Arikunto, Suharsimi.(1996). Prosedur Penelitian Suatu Pendekatan Praktik. Jakarta: Rineka Cipta. Arsyad, Azhar. (2015). Media Pembelajaran. Jakarta : Raja Grafindo Persada.

Hake, Richard R. (1998). Analyzing Change/Gain Scores. American Educational.

Kemendiknas. (2010). Pengembangan Pendidikan Budaya dan Karakter Bangsa. Jakarta.

Mardapi, Djemari. (2008). Teknik Penyusunan Instrumen Tes dan Non Tes. Yogyakarta: Mitra Cendikia Press.

Puspadewi, I G.A. dkk. (2016). Budaya dan Implikasinya terhadap Pembelajaran Matematika yang Kreatif. Universitas Mahasaraswati Denpasar. Jurnal Santiaji Pendidikan Volume 6 Nomor 1. (http://ojs.unmas.ac.id/index.php/JSP/article/view/669, diakses 1 Mei 2018)

Rusman. (2012). Belajar dan Pembelajaran Berbasis Komputer. Bandung: Alfabeta.

Sugiarti, Rina, I Nyoman Arcana. 2017. Pengembangan Media Pembelajaran Berbasis Komputer untuk Model Example Non Example pada Materi Geometri di SMP. Universitas Sarjaya Tamansiswa Yogyakarta, 1060-1066.

Sugiyono. (2016). Metode Penelitian Pendidikan. Bandung: Alfabeta.

Susilana, Rudi dan Cepi Riyana. (2011). Media Pembelajaran. Bandung: Wacana Prima.

Ulya, Himmatul. (2016). Pembelajaran Matematika Berbasis Etnomatematika untuk Membangun Karakter Cinta Tanah Air dan Kreativitas Belajar Matematika. Universitas Muria Kudus.

Yuliyanto, Sodikun Atmo. (2014). Memperkuat Karakter Cinta Tanah Air dan Pemecahan Masalah Siswa melalui Model Problem Based Learning Bermuatan Etnomatematika. Universitas Negeri Semarang. 